\title{
Development of Authentic Assessment in Basic Automotive Engineering Work Learning to Measure the Skills of X Grade Students of Hang Nadim Vocational High School in Batam
}

\author{
Yuyun Irowati ${ }^{1}$, Ridwan $^{2}$, Ambiyar $^{3}$, Ririt Dwi Putri Permatasari ${ }^{4}$, B. Herawan Hayadi ${ }^{5}$ \\ Master of Technology and Vocational Education Masters Program, Faculty of Engineering, \\ Padang State University ${ }^{1,2,3}$ \\ STT Ibnu Sina Batam Indonesia ${ }^{4}$ \\ University of Pasir Pengaraian, Riau Indonesia ${ }^{5}$ \\ \{yuyun.irowati86@gmail.com $\left.{ }^{1}\right\}$
}

\begin{abstract}
This research is motivated by the unavailability of the development of assessment instruments that are by the 2013 curriculum. Also, the usual assessment is the assessment carried out at the end of the learning program. This study aims to develop an authentic assessment instrument in basic automotive learning work learning to measure student skills that are valid, practical and effective. The type of research used is research and development (R \& D) with the ADDIE development model. The research subjects were Class X students of Hang Nadim Vocational High School in Batam, who took basic subjects in automotive engineering. The instrument for collecting data is in the form of a questionnaire. The data of this study were obtained through instrument validation sheets, practical questionnaires, and observations. The results of the validity test show that the Lesson Plan and authentic assessment developed are valid with a percentage of the average Lesson Plan of $95 \%$ and the average percentage of authentic assessment $96 \%$. The practical test results show that authentic assessment developed is very practical with the percentage of practicality average by teachers towards lesson plans is $93 \%$ and authentic assessment is $91 \%$. Based on the results of the effectiveness test, it was stated that authentic assessment developed was effectively used with $38 \%$ time series analysis which had a treatment effect on the value of completeness of students increased and obtained again score test of 0.38 with a moderate category. Thus, this study produces authentic assessment in basic automotive learning work learning to measure student skills that are valid, practical and effective.
\end{abstract}

Keywords: 2013 curriculum, ADDIE development model, lesson plan

\section{Introduction}

In improving the quality of education, a teacher's professionalism is demanded over time, because the teacher is the person who directly interacts with the students in the class. Matters relating to the main tasks and functions of the teacher must be mastered; skills are one of the assessments of learning outcomes. Evaluation can be done with an assessment of the quality of 
learning and can obtain information about the level of achievement of student competencies which includes competency attitudes, knowledge and skills[1], [2].

Assessment is an important component in the learning process because the learning process is a process of changing the behavior of students. A process in collecting, analyzing and interpreting information to determine the level of achievement of learning objectives by students is called assessment. In terms of teachers, a good assessment system can provide an overview of the quality of learning and can help in planning learning strategies. While in terms of students themselves, a good assessment system can motivate in improving their abilities. Through assessment, information can be obtained that can be used in making decisions about students, curriculum, programs, schools, and education policies[3]-[5].

In authentic assessment, in addition to paying attention to the attitudes (affective) aspects, knowledge competencies (cognitive) and skills competencies (psychomotor) and variations in instruments or test equipment used, we must also look at the input, process, and output of students. Assessment of student learning outcomes must also be done at the beginning of learning (assessment input), during learning (assessment process), and after learning (assessment output)[6], [7].

By the Authentic understanding assessment is to assess the ability of students, especially in terms of their skills, but not all teachers understand how to implement authentic assessment. The teacher applies authentic assessment only to the extent of his understanding, in accordance with the statement of the Minister of Education and Culture M. Noah that: the obstacles faced by the teacher in the 2013 curriculum training, namely the problem of learning assessment, where the teacher is still having difficulty applying the 2013 curriculum assessment concept in the learning process, whereas from the preparation of Lesson Plan factors there were no problem constraints. Because in the 2013 curriculum learning assessment, teachers were required to interpret the values written from the learning process activities until the end of learning.

\section{Method}

This research is development research that uses Research and Development (R \& D) design. Research and Development is a research model used to produce certain products, and test the effectiveness of these products.[8] This development research was designed to produce a product that is in the form of an authentic assessment instrument in inquiry-based Automotive Engineering Basic Work to measure the skills of X-grade students in light vehicle engineering at Batam Hang Nadim Vocational School. This development research product consists of five phases / stages namely 1) Analysis, 2) Design, 3) Development, 4) Implementation, and 5) Evaluation[9], [10].

The instrument used in this study is an instrument of validation, an instrument of practicality and an instrument of effectiveness.

1. Instrument Validation

Validation instruments in the form of validation sheets are used to collect data regarding the validity or failure of authentic inquiry-based assessment instruments developed. Validation is carried out by validators who are experts in their fields. The validation sheet will be filled in by the validator first validated; the validation sheet contains indicators that will be assessed by the validator in the form of eligibility content, the feasibility of construction (component presentation) and language components. Validation is carried out aimed at obtaining ratings, suggestions, and input regarding authentic assessment instruments developed. 
2. Questionnaire Practicality

Practical instruments are instruments used to gather information about the practice of authentic assessment developed. The instrument is in the form of a teacher response questionnaire on the practicality of each authentic instrument of assessment so that researchers can find out how easy it is to use authentic assessment in learning.

3. Instrument of Effectiveness

This instrument was developed to collect the effectiveness of authentic assessment data. The instrument used to assess the effectiveness of authentic assessment is to use student learning outcomes tests. Effectiveness is seen from the results of learning tests in the form of attitudes, knowledge, and skills. Learning outcomes are obtained by giving tests to students before and after using authentic assessment that is valid and practical.

\section{Result and discussion}

\subsection{Validity Test Data}

The results of the instrument's feasibility are obtained from the results of validation by experts using the instrument validation sheet. The results are as follows:

Table 1. Results of Validation of Lesson Plan

\begin{tabular}{|c|c|c|c|c|c|c|}
\hline \multirow{2}{*}{$\begin{array}{c}\text { Assessed } \\
\text { Aspects }\end{array}$} & \multicolumn{3}{|c|}{ Validator Assessment } & \multirow{2}{*}{$\sum \mathbf{s}$} & \multirow{2}{*}{ Aiken's V } & \multirow{2}{*}{ Description } \\
\hline & 1 & 2 & 3 & & & \\
\hline Item 1 & 5 & 5 & 5 & 12 & 0.750 & Valid \\
\hline Item 2 & 5 & 5 & 5 & 12 & 0.750 & Valid \\
\hline Item 3 & 5 & 5 & 5 & 12 & 0.750 & Valid \\
\hline Item 4 & 4 & 4 & 4 & 9 & 0.563 & Not Valid \\
\hline Item 5 & 4 & 5 & 4 & 10 & 0.625 & Valid \\
\hline Item 6.a & 5 & 5 & 5 & 12 & 0.750 & Valid \\
\hline Item 6.b & 5 & 5 & 5 & 12 & 0.750 & Valid \\
\hline Item 6.c & 5 & 5 & 5 & 12 & 0.750 & Valid \\
\hline Item 6.d & 5 & 5 & 5 & 12 & 0.750 & Valid \\
\hline Item 6.e & 5 & 5 & 5 & 12 & 0.750 & Valid \\
\hline Item 6.f & 5 & 5 & 5 & 12 & 0.750 & Valid \\
\hline Item 7 & 4 & 5 & 5 & 11 & 0.688 & Valid \\
\hline Item 8 & 5 & 4 & 4 & 10 & 0.625 & Valid \\
\hline Item 9 & 5 & 5 & 5 & 12 & 0.750 & Valid \\
\hline Item 10 & 5 & 4 & 4 & 10 & 0.625 & Valid \\
\hline Total & 72 & 72 & 71 & 170 & 0.708 & Valid \\
\hline
\end{tabular}

\subsection{Practicality Test Data}

The practical testing of authentic assessment instruments is done on the teacher. The analysis of the teacher's practical results on authentic assessment is as follows: 
Table 2. Results of Practicality of Lesson Plan \& authentic assessment by the Teacher

\begin{tabular}{cccc}
\hline \multirow{2}{*}{ No } & \multirow{2}{*}{ Practitioner } & \multicolumn{2}{c}{ Practicality Value (\%) } \\
\cline { 3 - 4 } & & Lesson Plan & authentic assessment \\
\hline 2 & Practitioner 1 & 95 & 94 \\
\hline 3 & Practitioner 2 & 95 & 88 \\
\hline Average & 90 & 91 \\
\hline
\end{tabular}

In the table above it can be seen that the average value of each authentic assessment instrument ranges from 91 to 93 which can be categorized as very practical. Based on suggestions from Automotive Teachers at Hang Nadim Vocational High School in Batam, authentic assessment instruments made can be used in daily learning activities and can be used as a guide for developing instruments in other Automotive Engineering Basic Work materials.

\subsection{Effectiveness Test Data}

Effectiveness is viewed from the KKM in a classical way with the time series method.

Table 3. Comparison of overall student scores with time series calculations

\begin{tabular}{clcc}
\hline No & Meetings & Average Value & Description \\
\hline 1 & Pre $_{1}$ & 71.27 & Not Completed \\
\hline 2 & Pre $_{2}$ & 71.18 & Not Completed \\
\hline 3 & Pre $_{3}$ & 71.5 & Not Completed \\
\hline 4 & Pre $_{4}$ & 72.41 & Not Completed \\
\hline 5 & Post $_{1}$ & 82.41 & Completed \\
\hline 6 & Post $_{2}$ & 82.41 & Completed \\
\hline 7 & Post $_{3}$ & 82.41 & Completed \\
\hline 8 & Post $_{4}$ & 82.41 & Completed
\end{tabular}




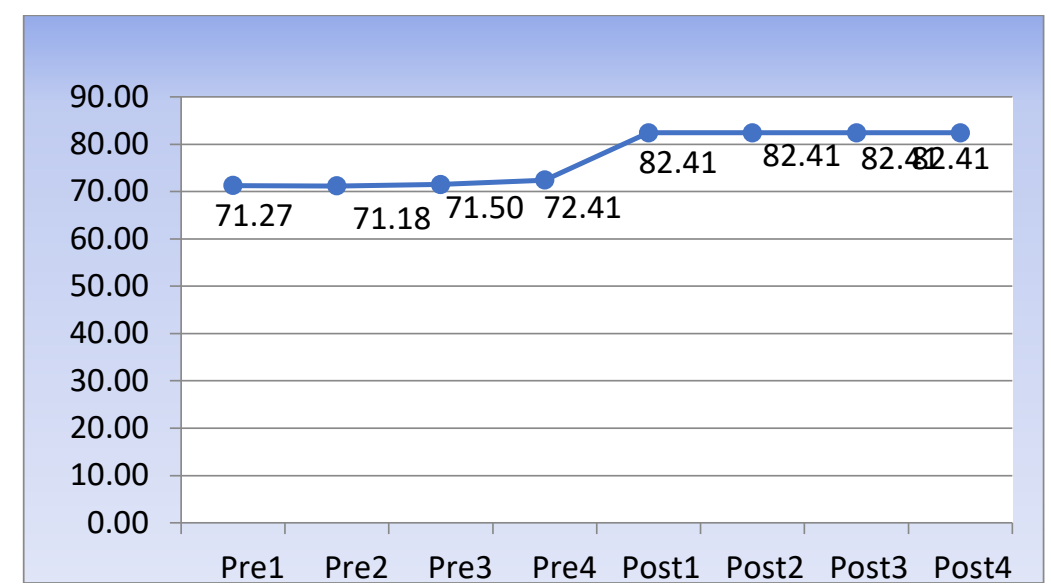

Figure 1. Comparison of overall student scores with time series calculations

\section{Conclusion and suggestions}

Based on the results of the study "Authentic assessment development in learning Basic Work of Automotive Engineering is to measure students' skills" which can be concluded as follows:

1. Authentic assessment instruments have been produced in the learning of Basic Automotive Engineering Works to measure students' skills using the ADDIE method. The authentic assessment instrument consists of attitude competency assessment, knowledge competency assessment, and skills competency assessment.

2. Authentic instruments of assessment in learning Basic Work of Automotive Engineering is to measure the skills of students developed to meet valid criteria. This is evidenced by completing the assessment stage given by expert lecturers to produce a valid, authentic assessment instrument.

3. Instruments of authentic assessment in learning Basic Work of Automotive Engineering is to measure the skills of students developed to meet practical criteria. This is evidenced by the practical value given by the teacher in a very practical category.

4. Instruments of authentic assessment in learning The Basic Job of Automotive Engineering is to measure the skills of students developed to meet the effective criteria. Aspects of effectiveness can be seen in the results of the analysis of student learning outcomes using time series and test gan-score.

Suggestions that can be given from the results of research for the next researcher include:

1. Conducting a more in-depth study of authentic assessment development in learning Automotive Basic Engineering work to measure student skills, with the aim of helping to improve the quality of future research.

2. Further research needs to be developed regarding authentic assessment development in learning Automotive Basic Engineering to measure students' skills towards different subject matter in order to develop and be useful for learning activities.

3. Development of instruments by adding more images to illustrate some statements and questions that are more communicative. 


\section{References}

[1] Z. Kaiqiang, K. Li, W. Qing, C. Hong, Z. Dehai, and C. Xinrong, "Ontology-Based Skills Knowledge Base Construction Method and Its Application in Educational Games," in 2014 11th Web Information System and Application Conference, 2014, pp. 249-253.

[2] H. A. Abdelaziz, "A Proposed Model for Designing Creative Interactive e-Learning Activities and its Impact on Developing Knowledge Generating, Depth of Learning, and Team Work Skills," in 2013 Fourth International Conference on e-Learning "Best Practices in Management, Design and Development of e-Courses: Standards of Excellence and Creativity,” 2013, pp. 276-279.

[3] H. Eguchi, K. Seki, T. Aoyama, and I. Koshijima, "Optimal job routine assignment for the improvement of operational resilience based on skills and knowledge of production staff in the chemical industry," in 2014 Joint 7th International Conference on Soft Computing and Intelligent Systems (SCIS) and 15th International Symposium on Advanced Intelligent Systems (ISIS), 2014, pp. 861-866.

[4] Gwangyong Gim and T. Whalen, "Dimensions of knowledge: fact or skill, quality or quantity," in NAFIPS/IFIS/NASA'94. Proceedings of the First International Joint Conference of The North American Fuzzy Information Processing Society Biannual Conference. The Industrial Fuzzy Control and Intellige, 1994, no. 1, pp. 447-448.

[5] S. Xu, T. Hu, and Q. Zhou, "A case study in Jiuwuji Minority Middle School on rural teachers' educational technology training in terms of a switch of educational product," in 2011 IEEE 3rd International Conference on Communication Software and Networks, 2011, pp. 318-320.

[6] D. Puyada, G. Ganefri, A. Ambiyar, R. E. Wulansari, and B. Herawan Hayadi, "Effectiveness of interactive instructional media on Electrical Circuits," Int. J. Eng. Technol., vol. 7, no. 2.14 Special Issue 14, 2018.

[7] M. Ropianto et al., "Optimization of Strategic Planning Organization in the Framework of Achievement Objectives of Education," in Proceedings of the 2nd International Conference on Education, Science, and Technology (ICEST 2017), 2017, vol. 149, no. Icest, pp. 149-151.

[8] O. U. Muhoza, M. Tedre, N. Aghaee, and H. Hansson, "Viewpoints to ICT Practices and Hindrances from in Tanzanian Secondary Schools and Teacher Training Colleges: Focus on Classroom Teachers," in 2014 International Conference on Teaching and Learning in Computing and Engineering, 2014, pp. 133-140.

[9] K. Rukun, B. H. Hayadi, and M. S. Hartawan, "Design and Analysis of Expert System Based on Information System to Diagnose Computer Failures Using Forward Chaining Method," Int. J. Eng. Technol., vol. 7, no. 3.5, pp. 124-126, 2018.

[10] B. H. zul azmi and B. Hayadi, "Design of Expert System to Determine Stock Investment Using Forward Chaining Method," Jour Adv Res. Dyn. Control Syst., vol. 10, no. 10, pp. 1869-1873, 2018. 